УДК 78.1.08

DOI: 10.37026/2520-6427-2021-105-1-124-127
Геннадій ФІСЬКОВ, дочент кафедри народних інструментів Інституту мистеитв Рівненського державного гуманітарного університету, м. Рівне, Украӥна ORCID: 0000-0003-3972-6653 e-mail:fiscoff@ukr.net

Олег ПАЛАЖЕНКО, кандидат педагогічних наук, доиент, доиент кафедри духових та ударних інструментів Інституту мистеитв Рівненського державного гуманітарного університету, м. Рівне, Украӥна

ORCID: 0000-0002-6992-8929

e-mail: palazhenkooleg@ukr.net

\title{
ОСОБЛИВОСТІ ФОРМУВАННЯ МЕТРОРИТМУ В СТУДЕНТІВ НА ЗАНЯТТЯХ В ОРКЕСТРОВОМУ КОЛЕКТИВІ
}

\begin{abstract}
Анотація. У статті аналізується ритм як особлива форма організаиії рухів та діяльності у часі та просторі, прочес формування досконалої метроритмічної структури в оркестрових музикантів, тимчасова організачія рухів, діяльності та поведінки особистості, щчо служить засобом втілення результатів інтерпретаиійного аналізу.

Схарактеризована ритмічна організачія як основа життя, адже все, що нас оточуе, живе за законами ритму. Доведено, щуо ритмічна здатність відіграє важливу роль у розвитку оркестрового музиканта. Формування почуття ритму здійснюється паралельно із розвитком емочиійноі, рухової та пізнавальної сфер музичного буття. Оркестровий колектив засобами мистеитва здійснює виховний вплив на студентів та надає їм відчуття естетичної значущості світу, пробуджує креативність, бажання творити й отримувати естетичну насолоду.

Підкреслено, шьо досконале відчуття музичного часу як основи метроритмічної структури твору залежить від досвіду оркестрових музикантів та їх уміння володіти інтерпретаційним художньо-образним бачен-
\end{abstract}

ням оркестрової партитури, в котрій викладено основні жанроутворювальні та стилевідповідні елементи, щзо можуть по-різному трактуватися виконавиями-оркестрантами. Таким чином, у формуванні чіткої метроритмічної структури у студентів на заняттях в оркестровому колективі важливу роль відіграють інтерпретаційні вміння, що на основі темпових та виконавсько-метричних особливостей дають змогу адекватно відтворювати музичний образ. Отже, виконавсько-інтерпретаційна складова є основою у формуванні метроритмічного чуття на заняттях в оркестровому колективі.

Зважаючи на зазначене вище, музичний час, у чітких рамках якого викладений музичний твір, схарактеризований не як суто метричне явище, а як художній засіб, шо врегульовує параметри співвідношення часу та музичних інтонацій, в результаті чого й відбувається розкриття музичного образу в залежності від стискання або розтягування музичного часу.

Ключові слова: ритм, метр, метроритм, інтерпретація, оркестр.

\section{Hennadiy FISKOV,}

Associate Professor of Folk

Instruments Institute of Arts

Rivne State University of Humanities,

Rivne, Ukraine

ORCID: 0000-0003-3972-6653

e-mail: fiscoff@ukr.net

\section{Oleg PALAZHENKO,}

Candidate of Pedagogical Sciences,

Associate Professor of the Department

of Wind and Percussion Instruments

Institute of Arts

Rivne State University of Humanities,

Rivne, Ukraine

ORCID: 0000-0002-6992-8929

e-mail: palazhenkooleg@ukr.net 


\section{FEATURES OF METRO RHYTHM FORMATION IN STUDENTS IN CLASSES IN THE ORCHESTRA}

\begin{abstract}
The article considers rhythm as a special form of organization of movements and activities in time and space, and the formation of a perfect metro-rhythmic structure in orchestral musicians as a temporary organization of movements, activities and behavior of the individual, which serves as a means of implementing interpretive analysis.

The problems of orientation of modern education on the integrated approach to the study of rational, creative and cultural-personal elements in the art of music in particular are becoming actual today.

In the course of mastering the art of respondents, in particular the basics of proper performance of works of art, which are based on tempo-rhythmic skills, which are the pinnacle of metro-rhythmic feeling of a musician, fully reveal the creative and artistic qualities of personality.

That is, the musical time within which the musical work is set out is not a purely metrical phenomenon, but to a greater extent acts as an artistic means that regulates the parameters of the ratio of time and musical intonations, which reveals the musical image depending on the compression or stretching of musical time.

Thus, the perfect sense of musical time that forms the basis of the metro-rhythmic structure of the work depends on the experience of orchestral musicians and their ability to have an interpretive artistic vision of the orchestral score which sets out the main genre-forming and stylistic elements that can be interpreted differently by different performers-orchestra players. Thus, in the foreground in the formation of a clear metro-rhythmic structure of students in the orchestral group are interpretive skills that allow on the basis of tempo and performance-metric features to adequately reproduce the musical image. Thus, the performing and interpretive component is the basis for the formation of metro-rhythmic sense in the orchestra.
\end{abstract}

Thus, rhythm is the most important element in creating a certain emotional mood in music and in revealing its certain artistic content. In general, we can conclude that the metro-rhythm in music is not only a temporal element, but also emotionally expressive, figurative-poetic and artistic-semantic categories of the interpretive vision of orchestral musicians.

Key words: rhythm, meter, metro rhythm, interpretation, orchestra.

Постановка проблеми. Інтеграція України в європейське товариство спонукає до перебудови загальноприйнятих аксіологічних пріоритетів, що вимагають певної зміни системи національної освіти. Нові суспільні потреби особистості базуються на художньо-освітніх програмах, в яких передбачено розвиток інтелекту, логіки та креативних здібностей акцептора в сучасних умовах творчої діяльності.

Особливої актуальності набувають проблеми зорієнтованості сучасної освіти на інтегрованому підході до вивчення раціонального, творчого та культурно-особистісного елементів у музичному мистецтві зокрема. Адже одним із першоелементів музики є ритм, який завжди був надважливим для музичного мистецтва. Проте існує певна проблема у визначенні дефініції «ритм» та його місця в системі засобів музичної виразності.
У музикознавстві трактування поняття «музичний ритм» вважається досить різнобічним і суперечливим. Ще за античних часів ритм трактувався як одна iз основних категорій живопису і скульптури. Саме тому давні греки означені види художньої творчості відносили до музичного мистецтва і поширювали на них музичні принципи.

У трактаті відомого філософа та мислителя Аврелія Августина «Про музику» були зроблені перші спроби ритмічної організації музики (Палаженко, 2012, с. 253). Осмислюючи метричні закономірності поезії та музики, середньовічний автор бере за основу числові закономірності та відкриває закони організації ритмів - рівність, відповідність, пропорційність. Це саме ті грунтовні властивості, які обумовлюють почуття задоволення, радості й насолоди.

Формотворчі характеристики музичного мистецтва, зокрема ритм, пульсація, рух, дія, описують одне й теж саме явище. Упродовж не одного десятка років педагоги ототожнювали рух із засобом музичного розвитку. У зв'язку з цим музиканти усвідомлювали важливість руху не лише як способу удосконалення тіла, але й як можливості формувати духовний світ людини. У прогресивних педагогічних системах музичного виховання руху відводилося особливе місце.

Для цілісного сприйняття та розуміння музики необхідний також ритм. Якщо людина зі шкільних років не розвиває відчуття ритму, вона не здатна повноцінно сприймати музику, тобто ії розуміння «музичної культури» буде неповним, а етико-естетичне виховання втрачатиме свої основні орієнтири (Палаженко, 2012. с. 254).

На сучасному етапі у процесі оволодіння респондентами музичним мистецтвом, зокрема основами правильного виконання художніх творів, основою яких $\epsilon$ темпоритмічні вміння як основа метроритмічного відчуття музиканта, повною мірою виявляються творчі та художньо-образні якості особистості.

Мета статті полягає в обгрунтуванні навичок метроритмічного відчуття у студентів на заняттях в оркестровому колективі.

Аналіз наукових досліджень і публікацій. Процес формування виконавсько-творчих умінь та навичок студентів у процесі творчої діяльності в оркестровому колективі аналізували такі науковці, як I. Маринін, О. Каргін, Є. Смирнова, В. Подкопаєв, С. Мальков, Ф. Соломонік, В. Чабанний, М. Соколовський та інші. Крім того, у сучасній психолого-педагогічній практиці останнім часом активізувалися дослідження, в яких висвітлено проблематику розвитку художньо-творчих здібностей. Зокрема, вивченням означеного питання займалися такі вчені, як Д. Богоявленська, Ю. Бабанський, В. Кан-Калик, В. Загвязинський, А. Маслоу, В. Кузін, Л. Оршанський та інші.

Варто також відзначити значні напрацювання щодо феномену музичного часу та темпоритму у працях Б. Деменка, В. Холопової, О. Глазиріна. Питаннями формування метроритму в ансамблевому та оркестровому колективах займилися В. Овод, Ю. Бай, І. Лаптєв, В. Лебедєв та ін. 
Праці Г. Ципіна, в яких схарактеризовано проблеми виконавських умінь та ритмічного чуття, в контексті нашого дослідження також набувають особливого методологічного значення. Не менш цікавими є роботи таких науковців, як С. Науменко, Н. Берегер, I. Таран, у котрих аналізується феноменологія метроритмічного чуття на початковому етапі навчання.

Виклад основного матеріалу дослідження. Музичне мистецтво відіграє надзвичайно важливу роль у формуванні творчої та духовно багатої особистості. Воно віддзеркалює естетичну складову буття, завдяки чому забезпечуються умови для вираження особистих потреб та отримання естетичної насолоди.

Ритмічна організація є основою життя, адже все, що нас оточує, живе за законами ритму. Зміна пір року, дня і ночі, биття серця - усе це та багато іншого підпорядковане певному ритму. Ритмічна здатність відіграє важливу роль і в розвитку оркестрового музиканта. Формування почуття ритму здійснюється паралельно із розвитком емоційної, рухової та пізнавальної сфер музичного буття.

Оркестровий колектив засобами мистецтва виховує студентів, надає їм відчуття естетичної значущості світу, пробуджує креативність, бажання творити й отримувати естетичну насолоду. Зважаючи на це, формування почуття ритму у здобувачів закладів вищої освіти на заняттях в оркестровому колективі - одне із найважливіших завдань музичної педагогіки.

Б. В. Асаф’єв (1965) підкреслював, що музичний ритм легко відчути, але нелегко визначити. Творче почуття відтворення музики дарує відчуття ритмічного життя і навіює інтуїтивне проникнення в поетичний образ.

Б. М. Теплов (1985) із цього приводу зазначав, що художньо-змістовне виконання музики створює природні передумови для виховання і розвитку музично-ритмічного відчуття, що розуміється як здатність активно переживати музику і внаслідок цього тонко відчувати емоційну виразність тимчасового ходу музичного руху.

Видатний музикознавець Г. Преображенський (1975. с. 62) стверджував, що «... в оркестрі збираються студенти, кожен з яких має свій художній смак, своє уявлення про ідею та характер того або іншого твору, своє розуміння фразування, штриха, тембру». Дослідник займався виявленням та подоланням метроритмічних труднощів, які виникали у оркестрантів у процесі репетиційної роботи. На його думку, найбільш гостра проблема оркестрового музиканта полягає у відчутті метру, темпу та ритму.

Як зазначає О. Д. Тарківська-Нагиналюк (2015, с. 164), формування ансамблево-виконавського та оркестрового чуття відбувається безпосередньо в колективі, а готовність до виконання може базуватися лише на досвіді колективного виконання та на основі набутого індивідуально-виконавського чуття. Необхідно зазначити, що у цьому випадку відбувається конфлікт суб' єктивного сприйняття та виконавсько-інтерпретаційного досвіду, що базується на індивідуальних музично-виконавських здібностях, котрі виявляється у сприйнятті себе в оркестровому виконавстві та формуванні ансамблево-виконавського чуття.

В ансамблевому та оркестровому виконанні дотримання ритмічних довжин особливо актуальне, адже за цієї умови ритм найбільше прив’язаний до метру. С. Фейнберг щодо цього стверджував: «ритм в оркестрі підкоряється об'єктивним законам. Він є ближчим до метру, оскільки нотна величина в цьому випадку сковує темперамент багатьох виконавців» (ТарківськаНагилюк, 2015, с. 165).

Загалом у кожного оркестрового музиканта у ході рефлексії метроритмічного чуття можна виокремити зовнішні та внутрішні подразники дотримання часових параметрів. До зовнішніх подразників, що покликані формувати метроритмічну структуру в оркестрового музиканта, належать власне рахування долей, рахування долей такту викладачем або застосування метроному. До внутрішніх відносимо внутрішнє рахування, внутрішню пульсацію, а також відчуття відрізків звучання шляхом їх зіставлення.

Отже, можна стверджувати, що метроритмічне чуття у студентів в оркестровому колективі формується завдяки здатності, що підпадає під відповідний педагогічний вплив, а також базується на власній виконавській діяльності, яка сприяє музичному метроритмічному вихованню студентів, створює умови, за яких відбувається позитивне формування означеного феномену.

Як відомо, функції музичного ритму не вичерпуються моментами, пов'язаними із вимірюванням та організацією тривалостей у часі. Одним із основних елементів музики є засоби виконавської виразності, тому ритм майже завжди відображає емоційний зміст музики, їі образно-поетичну сутність. Це і є першою особливістю ритму, що в музиці пов'язує його $з$ передачею різних станів людини, втіленням у ній складних проявів іiї внутрішньої організації.

Важливу роль у музичному метроритмічному вихованні студентів в оркестровому колективі відіграє відчуття ритмічного стилю музики, розуміння специфічних особливостей цього стилю. Для кожної епохи та конкретного історичного періоду характерний певний музичний метроритм, що виявляється у своєрідності та неповторності композиторської творчості та індивідуальності.

У нашому дослідженні ритм розглядається як особлива форма організації рухів та діяльності у часі й просторі, а формування досконалої метроритмічної структури оркестрових музикантів трактуємо як тимчасову організацію рухів, діяльності та поведінки особистості, що служить засобом втілення результатів герменевтичного аналізу. Тобто музичний час, у чітких рамках якого викладений музичний твір, не є суто метричним явищем, а переважно художнім засобом, що врегульовує параметри співвідношення часу та музичних інтонацій, у результаті чого й відбувається розкриття музичного образу в залежності від стискання або розтягування музичного часу.

Висновки. Отже, досконале відчуття музичного часу, що становить основу метроритмічної структури твору, залежить від досвіду оркестрових музикантів та їх уміння володіти інтерпретаційним художньо-образним баченням оркестрової партитури, в якій викладено основні жанроутворювальні та стилевідповідні елементи, що можуть по-різному трактуватися виконавцями-оркестрантами. Таким чином, важливу роль у формуванні чіткої метроритмічної структури у студентів на заняттях в оркестровому колективі виконують інтерпретаційні вміння, що дають змогу на основі 
темпових та виконавсько-метричних особливостей адекватно відтворювати музичний образ. Зважаючи на зазначене вище, виконавсько-інтерпретаційна складова $є$ основою у формуванні метроритмічного чуття на заняттях в оркестровому колективі, а ритм вважається найважливішим елементом у створенні певного емоційного настрою в музиці та у процесі розкриття іiі художнього змісту.

Перспективи подальших досліджень вбачаємо в аналізі метроритму в музиці не лише як часовимірювального елемента, а й емоційно-виразної, образно-поетичної та художньо-смислової категорії інтерпретаційного бачення оркестрових музикантів.

\section{СПИСОК ВИКОРИСТАНОЇ ЛІТЕРАТУРИ}

Палаженко, О. П. (2012). Особливості розвитку навичок ритму як складової музичної культури у дітей підліткового віку. Луганськ: ЛДШКМ. С. 253-254.

Асафьев, Б. В. (1965). Избранные статьи о музыкальном просвещении и образовании. Москва: Музыка. 151c.

Теплов, Б. М. (1985). Психология индивидуальных различий. Способности и одаренность. Психология музыкальных способностей. Москва: Педагогика. 328 с.

Преображенский, Г. Н. (1975). Оркестровый класс как средство воспитания музыканта-исполнителя, педагога, дирижера. Ленинград: Музыка. 500 с.

Тарківська-Нагилюк, О. Д. (2015). Особливості виховання метро-ритмічного чуття в ансамблевому виконавстві. Науковий часопис НПУ імені М. П. Драгоманова. Серія 14 «Теорія і методика мистеиької освіти». Київ. С. 163-167.

Апатский, В. Н. (2010). История духового музыкально-исполнительского искусства. Київ: ТОВ «Задруга». $320 \mathrm{c.}$

Падалка, Г. М. (2008). Педагогіка мистецтва. Теорія і методика викладання мистещьких дисииплін. Київ: Освіта України. 274 с.

Холопова, В. Н. (2014). Музыка как вид искусства. Москва: Планета музыки. 320 с.

\section{REFERENCES}

Palazhenko, O. P. (2012). Osoblyvosti rozvytku navychok rytmu yak skladovoi muzychnoi kultury u ditei pidlitkovoho viku [The special features of development are a quick start to the rhythm of musical culture among children of the age group]. Luhansk: LDShKM. S. 253-254. [in Ukrainian].

Asafev, B. V. (1965). Yzbrannye staty o muzykalnom prosveshchenyy y obrazovanyy [Selected articles on music education and education]. Moskva: Muzyka. 151s. [in Russian].

Teplov, B. M. (1985). Psykholohyia yndyvydualnыkh razlychyi. Sposobnosty y odarennost [The psychology of individual differences. Abilities and giftedness]. Psykholohyia muzykalnykh sposobnostei. Moskva: Pedahohyka. 328 s. [in Russian].

Preobrazhenskyi, H. N. (1975). Orkestrovyi klass kak sredstvo vospytanyia muzykanta-yspolnytelia, pedahoha, dyryzhera [Orchestral class as a means of educating a musician-performer, teacher, conductor]. Lenynhrad: Muzyka. 500 s. [in Russian].

Tarkivska-Nahyliuk, O. D. (2015). Osoblyvosti vykhovannia metro-rytmichnoho chuttia $\mathrm{v}$ ansamblevomu vykonavstvi [Peculiarities of the metro-rhythmic chuttya in the ensemble viconavity]. Naukovyi chasopys NPU imeni M. P. Drahomanova. Seriia 14 «Teoriia i metodyka mystetskoi osvity». Kyiv. S. 163-167. [in Ukrainian].

Apatskyi, V. N. (2010). Ystoryia dukhovoho muzykalno-yspolnytelskoho yskusstva [The history of musical and performing arts]. Kyiv: TOV «Zadruha». 320 s. [in Ukrainian].

Padalka, H. M. (2008). Pedahohika mystetstva [Pedagogy of mystery]. Teoriia i metodyka vykladannia mystetskykh dystsyplin. Kyiv: Osvita Ukrainy. 274 s. [in Ukrainian].

Kholopova, V. N. (2014). Muzyka kak vyd yskusstva [Music as an art form]. Moskva: Planeta muzyky. 320 s. [in Russian].

Дата надходження до редакиії: 24.01.2021 p. 